\title{
Catherine Breniquet How Writing Came about in Glozel, France
}

\begin{abstract}
Glozel is a small hamlet in Ferrière-sur-Sichon, a rural district in the French Bourbonnais near Vichy, Central France. In the 1920s, it became an archaeological 'hot spot' when various strange artefacts made of clay and stone were 'discovered' in a field there. These objects included clay tablets containing writing in an unknown script, which suggested that writing had appeared there earlier than anywhere else. Authentic items to some scholars, but forgeries to others, the Glozel finds quickly became one of the most famous scientific controversies of the twentieth century in France, even involving the judiciary.
\end{abstract}

It is hard to imagine all the commotion about it today as the place and the various arguments concerning the affair have more or less been forgotten. However, in the 1920s, the controversy about the authenticity of the site grew into a major one. How is it that so many scholars were tricked by the finds? Just pronouncing the name 'Glozel' set the entire Auvergne on fire for years afterwards right up to the 1980s.

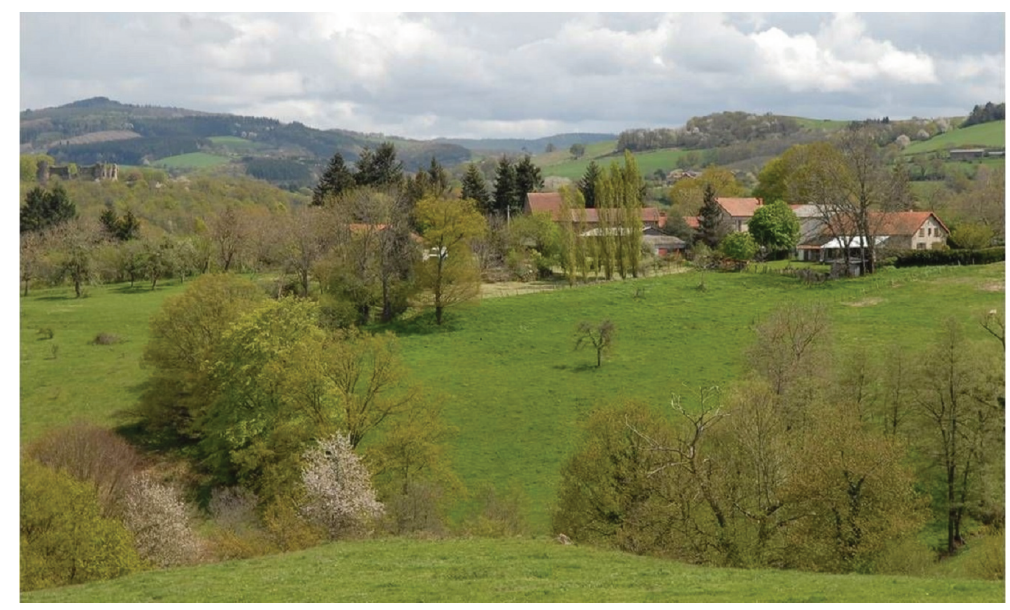

Fig. 1: General view of the hamlet of Glozel. The site is below, in the background (photograph by the author).

Ә Open Access. () 2020 Catherine Breniquet, published by De Gruyter. (cc)BY-NC-ND This work is licensed under the Creative Commons Attribution-NonCommercial-NoDerivatives 4.0 International License. 
In order to shed some light on the matter, a brief summary of this complicated affair will be presented here first of all. The written documents about the writing found on the artefacts is the focus of the second part of the paper, while the third section examines the scientific context of the period, which is key to understanding why the affair had such an impact.

\section{A short history of the Glozel affair}

The story began when a young man called Émile Fradin and his grandfather were ploughing a field of theirs on 1 March $1924 .{ }^{1}$ The wheel of the plough suddenly dropped down into the earth, into a pit which was possibly a grave or a glass-maker's oven from an unknown date. The two peasants started digging in order to get the plough out of the hole. Rather than filling the hole in, Emile Fradin, who was 16 at the time, removed the stones around it and claimed a few days later that he had made some extraordinary discoveries there and elsewhere in the field, known first as 'Les Durantons' and afterwards as 'Le Champ des Morts'. Some local teachers soon became aware of the findings: first of all, Mrs Adrienne Picandet visited the place and then informed the authorities about the site. Shortly after that, Mr Benoît Clément, another school teacher who came from La Guillermie, went to the field to make a scientific report on the find for the Société d'Émulation du Bourbonnais and applied to the same Société for a small grant, but was refused because money was lacking. Mr Clément then advised Dr Antonin Morlet, an eminent and respected doctor from Vichy and an amateur archaeologist in his free time, to conduct an archaeological dig in Glozel. The latter rented the field from the peasants, requested Émile Fradin to work with him on his own excavations and offered him the property rights to any objects found at the site. This would provide some credible justification for any future finds (it would be unlikely for a peasant family, presumably almost illiterate, to have faked the whole thing) and would create a lucrative business in future as well. Whether or not these two ideas were suggested to Morlet or were his own - or simply pure coincidence - is impossible to say.

One should bear in mind here that being an archaeologist was not a fulltime profession in France in this period. Most archaeologists were actually local people with some degree of authority by way of their main profession (doctors,

1 For an overview of the affair, see Reinach 1928a and 1928b; Morlet 1932; Torchet et al. 1978; Glozel 1983, Bessy et al. 1993. 
chemists, solicitors, teachers or members of the clergy, for example). Most, if not all, were members of local sociétés savantes, so they would have been likely to have had a good understanding of local history and their local area. Furthermore, the society officials would have been aware of current research at that time.

Focusing on the main discoveries here (except for some flint and glass artefacts, which could well be genuine), the Glozel archaeological findings are an assortment of bone figurines and pendants reminiscent of famous prehistoric pieces such as the 'Vénus de Brassempouy', clay objects and anthropomorphic pots (with a clear connection to Trojan material). There are also numerous bisexual objects made of clay, ${ }^{2}$ but of unknown use, and tablets with a hand imprint or an unknown script on them reminiscent of the Phoenician alphabet. Despite the presence of written documents, and compared with other wellknown sites, these artefacts mainly seemed to be Palaeolithic or Neolithic to scientists in the 1920s. ${ }^{3}$

A first surprising observation concerns the layout of the site. The field slopes considerably and it is impossible to find any stratigraphic layer in situ in Glozel (no soil, no architecture, and no pits or graves). This observation is not obvious in itself; it is always possible to admit we are facing considerable subsidence here. Owing to the slope and this possible subsidence, the original location of the artefacts would probably have slipped down towards the valley from the upper part of the field. A situation of this kind would have brought broken or damaged objects up to the surface, however, which is not the case; all the objects were still intact and, indeed, complete. Findings like these rarely occur in normal archaeological digs, except in primary graves where objects are usually found in a broken condition (along with rubbish). Many witnesses said they had seen objects extracted from the earth during the archaeological excavation. This leads us to the conclusion that the site in Glozel is unlikely to have been an ancient one. Due to the archaeological methods of the 1920s, which are now considered inappropriate, it is reasonable to assume that people may have got confused or carried away and failed to recognise the real situation. Pictures taken on site also show the great disorder in the field's terrain caused by strollers from the village, visitors, tourists and so on. ${ }^{4}$

2 Objects with male and female attributes; the term 'bisexual' is used to describe the objects in the original reports.

3 Morlet/Fradin 1925-1928.

4 Delporte 1983, 75-77. 
In order to get a reasoned scientific evaluation of the affair (which increased day after day and soon became impossible to control), an International Commission was set up in 1927..$^{5}$ This body involved eminent experts from the field of archaeology such as Salomon Reinach, Pere Bosch-Gimpera and Denis Peyrony. These authorities on prehistory, one of whom was Dorothy Garrod, the first woman to become a professor at the University of Cambridge and a scholar with extensive experience of working in difficult fields, expressed great reservations about the authenticity of the site. ${ }^{6}$ Indeed, small pits dug intentionally from the surface were observed in which objects may have been placed deliberately. Together with other eminent scientists with whom the Commission had connections, the scientific board of the Commission quickly split into two factions. Among the believers in the site's authenticity were Salomon Reinach, Auguste Audollent (a local professor) and Arnold Van Gennep (who was more cautious in his interpretation), all of whom were involved in the study of historical periods. The opponents included the prehistorians Comte Bégouen, Denis Peyrony, Abbé Breuil, Louis Capitan, André Vayson de Pradennes ${ }^{7}$ and René Dussaud, the renowned specialist in Oriental writing. The variety of expert opinions and evidence, however, prevented them from coming to any definitive conclusions as a result of their studies.

Despite the precarious position and viewpoint held by scientists at the time, hundreds of papers in French, international newspapers and scientific reviews were published, including books written both by renowned scientists and amateurs in the 1920s and later (indeed, well into the 1960s). It is practically impossible to know how many times Glozel was quoted in the literature that was published. The place became an archaeological mystery for a large part of the population, depicting an unknown people who may have invented writing earlier than anywhere else in the world. Moreover, as a real archaeological fact, Glozel might have gone against the official reconstruction of France's history. Some people thought that this 'evidence' was kept secret.

Later on, in 1983, a second commission manned by eminent French archaeologists, including Jean-Pierre Daugas, Jean-Paul Demoule, Jean Guilaine and Jean-Claude Poursat, stated their viewpoint as to the absence of an archaeological site in Glozel in the periphery of Le Champ des Morts. ${ }^{8}$ They drew attention to the presence of numerous glass residues belonging to a craftsman's

\footnotetext{
5 Morlet 1928.

6 See the overview in Garrod 1968.

7 Vayson de Pradenne 1930.

8 Daugas et al. 1995.
} 
workshop located there in modern times. The field has been badly disturbed by the diggings of the 1920s more or less everywhere. Another argument the Commission developed relates to the acidity of the soil in the area, which would probably have destroyed any object made of bone or clay after several decades. If this is true, it might invalidate claims about the discovery of intact artefacts. Many, if not all, of the artefacts may have been forgeries made by unknown individuals. Contrary to this viewpoint, there is evidence that some of the finds - particularly the oval objects - may be authentic and have been baked in a glass-maker's oven. If so, these artefacts could belong to the Iron Age, the Middle Ages or Early Modern Times. Physical and chemical analyses were conducted under the auspices of the French Ministry of Culture using modern techniques (spectrography, thermoluminescence or carbon-14 dating) involving numerous laboratories around the world that specialise in glass, pottery or bone object identification. ${ }^{9}$ Various dates appeared as a result: 'mediaeval', the thirteenth century CE, the Iron Age, Gallo-Roman times and even the twentieth century! This was enough to maintain suspicion that could distort the official scientific evaluations. It is also possible that the samples were contaminated significantly or that real archaeological materials were used to make forgeries. The Carte archéologique de la Gaule for the Département de l'Allier left some ambiguity as to the authenticity and nature of the site in $1989 . .^{10}$

\section{The written objects}

A number of unusual objects were among the artefacts the Glozel excavation brought to light. It is hard to say exactly how many inscribed objects were found there, though, as reports mention about 34 tablets, but some other written objects also existed. The most stunning pieces of all were clay tablets, square and rectangular in shape, covered by signs in an unknown, undeciphered script (see Figs. $2 \mathrm{a}$ and $\mathrm{a}$, and $2 \mathrm{~b}$ ). Most of the tablets are intact and are curiously bigger than tablets usually are (they can easily be held in one hand): around $20 \mathrm{~cm}$ high, and even $33 \mathrm{~cm}$ in some cases. The signs have mostly been written in lines and are incised. All in all, 133 signs were recorded.

The tablets are not the only objects covered in writing; other artefacts - the precise number is unknown - bear inscriptions, too, such as anthropomorphic

9 McKerrell et al. 1974.

10 Corrocher et al. 1989, 104 (under no. 203 for Ferrières-sur-Sichon). 
vases (Fig. 2c), stone bracelets (Fig. 2d), pebbles and even a small, engraved stone slab with the appearance of a reindeer (Figs. 2e and e').
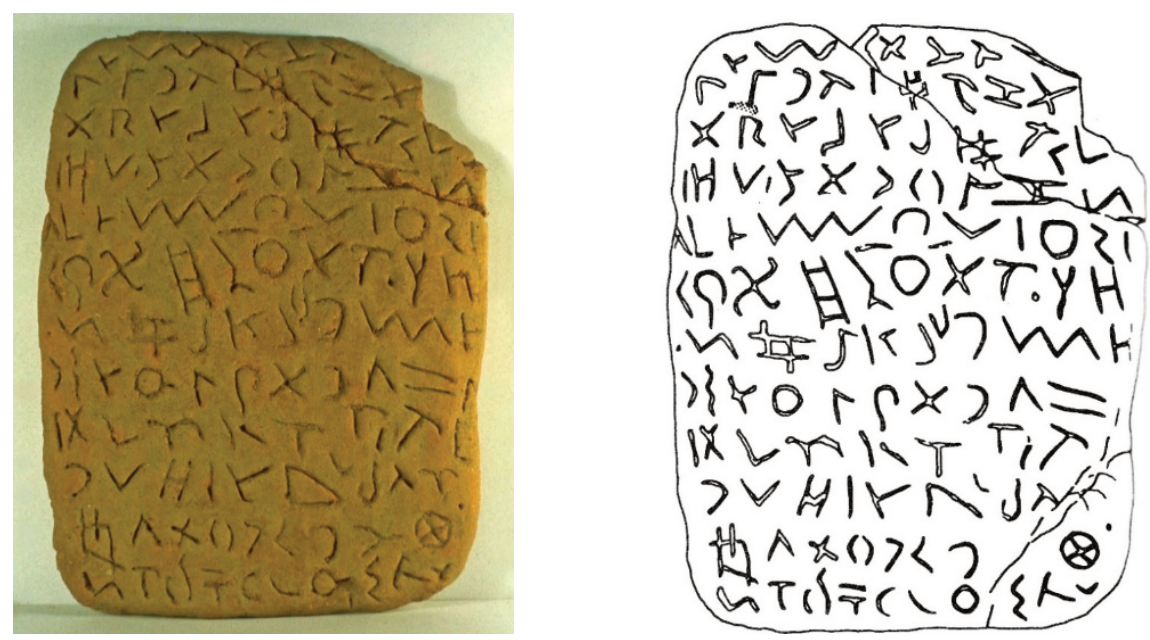

Fig. 2a and 2a'
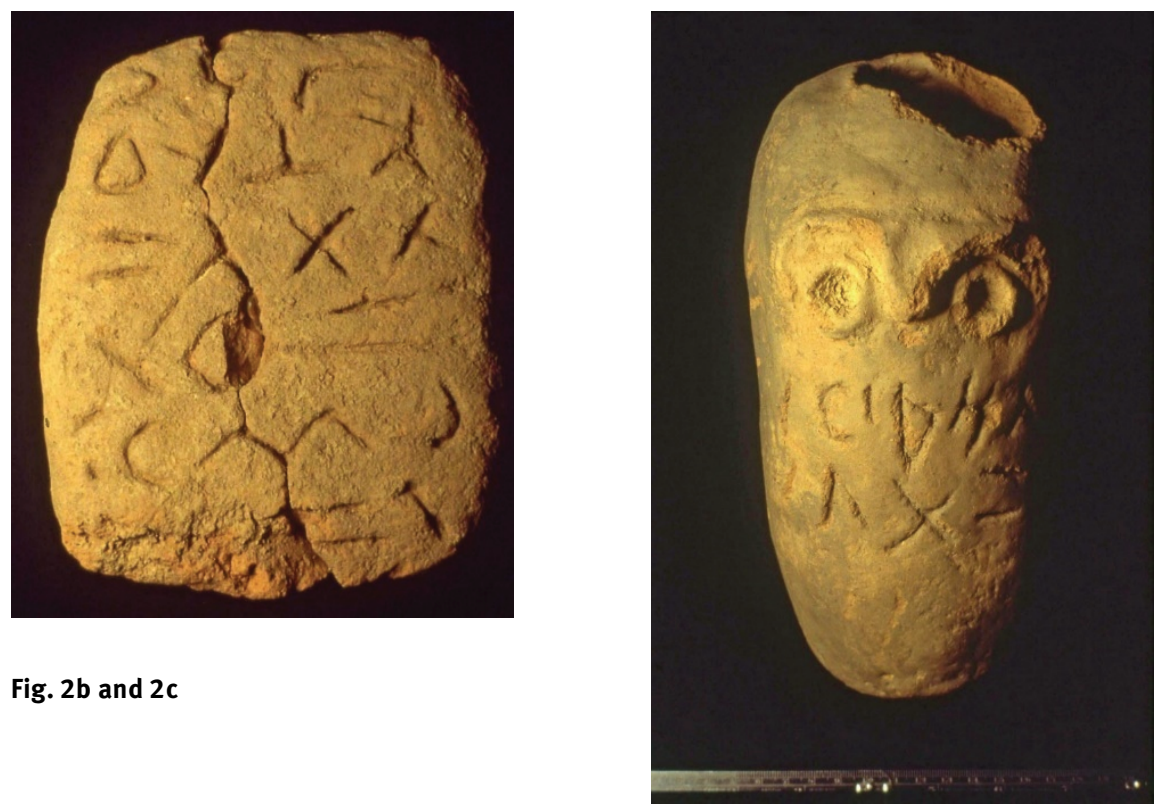

Fig. $2 b$ and $2 c$ 


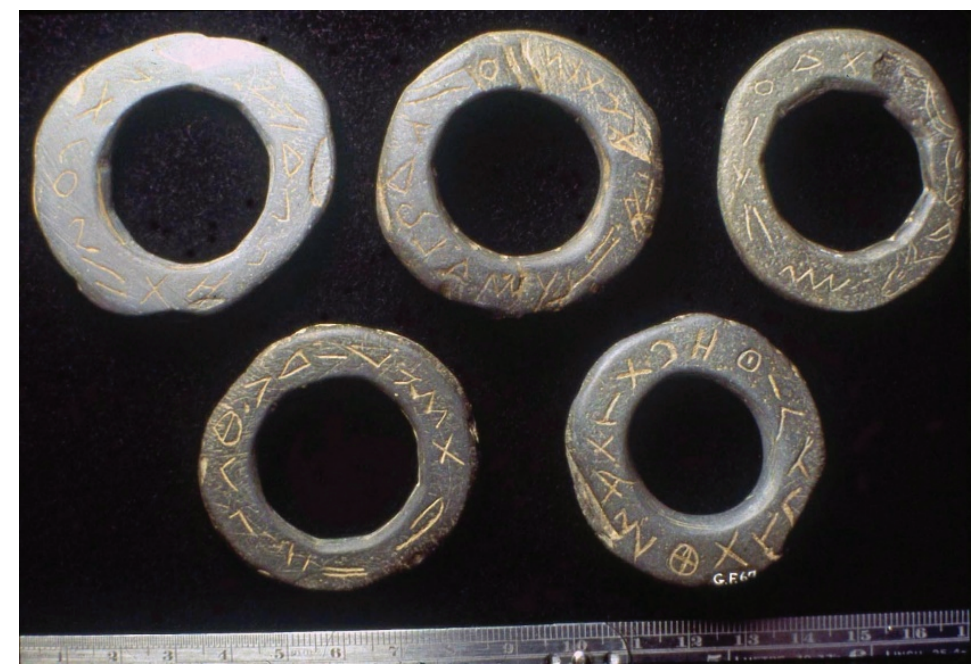

Fig. 2d
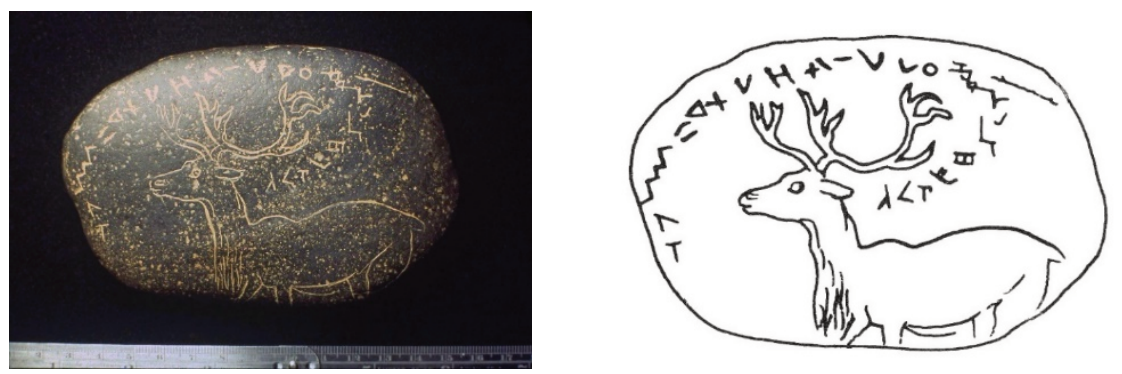

Fig. $2 \mathrm{e}$ and $2 \mathrm{e}^{\prime}$

Fig. 2: A selection of written objects from Glozel: a: tablet from Glozel - $\mathbf{a}^{\prime}$ : the same tablet redrawn from Reinach 1928a, pl. II-2 - b: small tablet - c: anthropomorphic vase - d: stone rings or bracelets - e: pebble with a 'talking reindeer' - e': the same pebble redrawn from the photograph. Photographs by Patrick Ferryn <http://www.kadath.be/media/glozel.html>, under free licence; (c) Photo Kadath - Patrick Ferryn.

Items of this type bring several problems to light:

- the larger-sized tablets are quite unusual;

- the material and/or objects that bear such inscriptions are clay or stone (written pots are quite unusual finds in archaeology, especially 
anthropomorphic vessels. Stone plaques engraved with Palaeolithic iconography are unknown, so the one from Glozel is unique); and

- the date of the material: the stone plaque looks Palaeolithic, the stone bracelets or rings could be Neolithic, and the vessels could date to the Neolithic or Bronze Age. Summarising, these artefacts seem to be very mixed and therefore cannot be readily assigned to a single period with absolute certainty.

Some tablets were covered by diluted clay or mud, producing a kind of patina with marks that appear to have been made by a brush. In Émile Fradin's house, Court officials found a pot with the same mud on it, but in another colour, and confiscated it, but Fradin claimed that his younger brother only used it to play with the mud. Most of the tablets were made with well-levigated clay, but in some of the analysed samples it was possible to determine the presence of some unusual fresh elements inside the paste, such as apple seeds or small leaves, and even fibres of cotton or wool. In one famous example, vegetal roots described as calcified were embedded in the clay, suggesting that the tablets had not been fired. Surprisingly, the roots had not been altered by several thousand years of exposure to the acidic soil. They did not break the tablets either. Additionally, the hole through which a root went in a tablet was filled with another form of clay, suggesting that it had been introduced in it deliberately. ${ }^{11}$ Samples of the tablets were cut into pieces and put in water for testing (twice, in fact: in the 1920s and 1980s). ${ }^{12}$ Some of the tablets dissolved quickly, showing that they were not all compacted the same way. Leaving the question of the writing on them aside for the time being, it seems clear that these tablets are, in fact, recent forgeries.

Other issues appear when we turn to the question of the writing on the tablets. All the specialists found that the Glozel signs were reminiscent of the Phoenician alphabet. ${ }^{13}$ However, no trace of Phoenician writing is attested in France for the supposed dating of the material between 700 BCE and 100 CE (according to thermoluminescence dating on written materials). During this span of time, the Greek alphabet is attested in the south of France (due to the presence of Greek colonies there), followed by the Latin alphabet during the Roman period. The Etruscan alphabet existed, too, in the eastern part of France. It has

11 Adam 1975, 79-83.

12 Adam 1975, 75-77 and Fig. 4.

13 See Fig. 3 and Adam 1983. 
been impossible to determine the direction of the writing on the tablets: from right to left or vice versa, or even bi-directional. ${ }^{14}$

Several interpretations emerged from these observations:

- The Glozel writing is a cursive script from the Gallo-Roman period mixed with magic signs such as those that can be seen on the lead Defixionum tabellae. This hypothesis was presented by Camille Jullian and August Audollent. ${ }^{15}$ The latter was a specialist in this type of magical writing and had a collection of lead tablets of his own from Carthage, where he had worked. This impressive collection is now stored at the Musée Bargoin in Clermont-Ferrand.

- The Glozel writing was invented by a local people at the end of prehistoric times or the beginning of the Neolithic period, well before writing appeared anywhere else in the world. This proposal was put forward by Émile Fradin and Dr Morlet, ${ }^{16}$ who were followed by Émile Espérandieu.

- Some variations of this hypothesis suggest that the writing could have been invented by an unknown people who arrived at Glozel at that time (from where?) and disappeared shortly after.

- The Glozel writing is certainly a mystery. It is impossible for us to say whether the signs are alphabetical, syllabic, ideographic or even numerical, hence the writing has still not been deciphered yet. The conjecture about its origins was so uncomfortable to scientists that the truth was kept hidden from local citizens; Glozel's archaeological history was turned into a parascientific affair instead in the 1960s. ${ }^{17}$

- More recently, a computer analysis brought to light that there is no more than one duplication of six signs in the material. ${ }^{18}$ This suggests that the socalled 'Glozelian language' does not actually exist at all and that the way the written signs have been organised is simply random. The existence of an early form of writing in France at the end of the Palaeolithic period is highly unlikely in view of current archaeological and scientific analyses.

\footnotetext{
14 Crawford 1977.

15 Audollent 1927.

16 Morlet/Fradin 1925-1928; Morlet 1955.

17 Castigated by Adam 1975, 1983 and 1988.

18 Crawford 1977.
} 


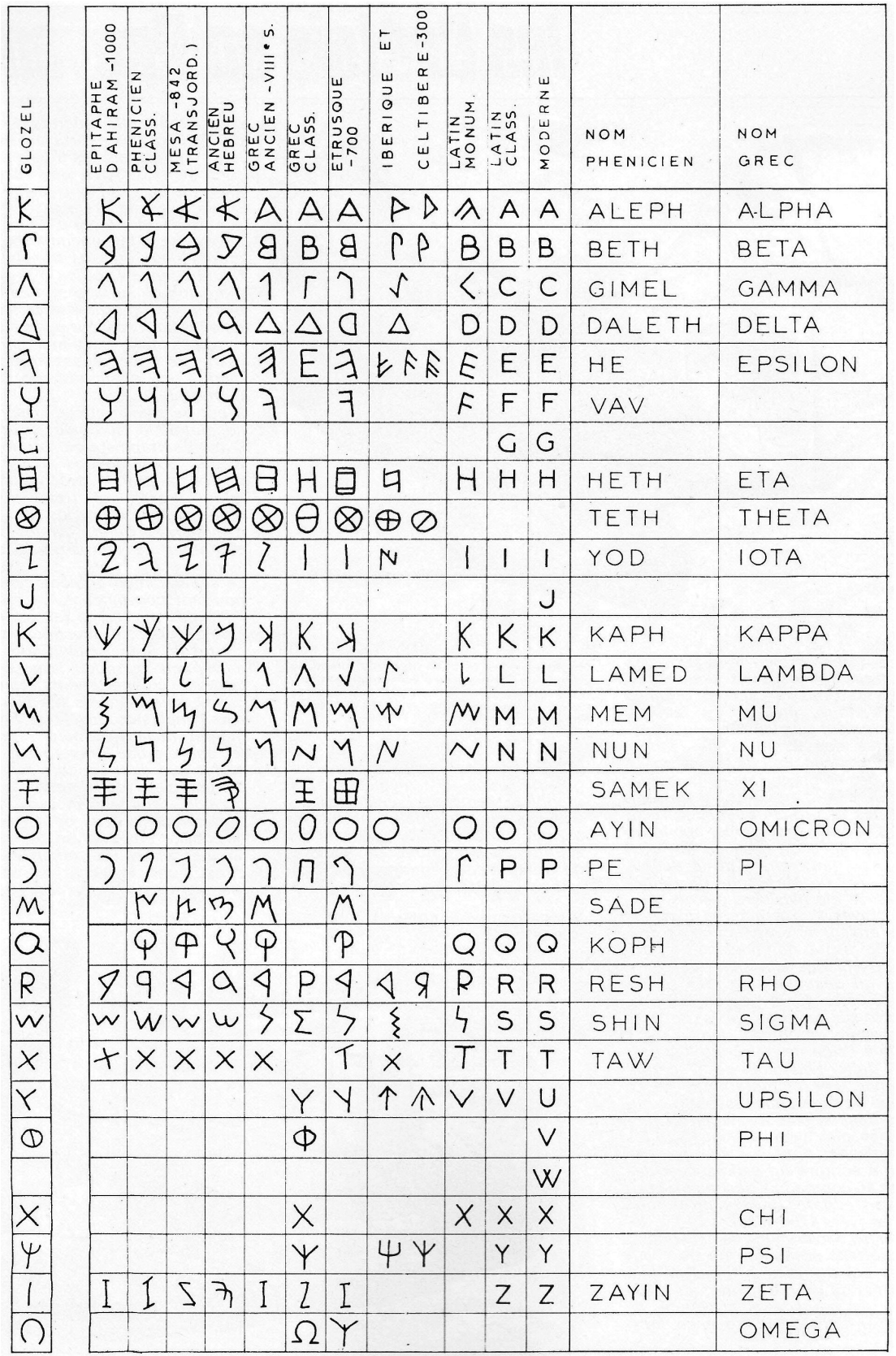

Fig. 3: The Glozelian letters, in comparison with the other known alphabets (cited in Adam, 1983, 69). 
One can conclude that both the sloping configuration of the site, the acidity of the soil there, the existence of complete artefacts rather than broken shards, and the direct parallels with archaeological pieces known at the time strongly suggest that the Glozel site is a sham and that most of the objects 'discovered' are fakes. Archaeological science and investigations have not been able to provide any information as to why this hoax was set up.

\section{The historical context}

As in other cases of archaeological forgery, the most interesting point about the Glozel site is the context of the affair: it involved local people and probably other unidentified persons at a higher level as well.

For a modest peasant in the 1920s, Glozel quickly became a highly lucrative business. The village is close to Vichy, a place where wealthy people, including officials and colonial administrators, used to go regularly for health reasons. Trips to the theatre, the racecourse for horse-racing and the casino filled their free time, but an archaeological affair would probably have been perceived as much more exciting. A regular bus route was set up quickly for tourists, curious onlookers and scholars who wanted to make the journey to the site, as Vichy would soon host the Congress of Prehistory. ${ }^{19}$ A museum was opened in 1926 at the Fradins' farm and exhibited more than 2,500 items. Thanks to the income generated from it, Émile Fradin soon owned his own car and he became a local celebrity portrayed on postcards sold by local booksellers. He even wrote books about the finds, the site and his own life. ${ }^{20}$ The perfect culprit, he was suspected of having made fake artefacts. He was accused of forgery by the Court of Justice, but eventually acquitted as no evidence of his 'workshop' was ever found. Fradin died in 2010 at the age of 103 without having addressed the circumstances of the discoveries; he only wrote books and papers about his life and the objects that had been unearthed at the site. He cannot be suspected of being a forger any longer. His only shortcoming at the end of the day (if it is one at all) is to have taken advantage of the situation and made money out of it. But was that really a crime for a family living in very modest circumstances? Since he was such a renowned doctor, Morlet was never taken to court or even suspected of being involved. He was probably honest or simply naive, or possibly both, as he

19 Glozel 1983, 53.

20 Morlet/Fradin 1925-1928; Fradin 1979. 
generally spoke in defence of Fradin. Nobody else was suspected. The truth of the matter is probably buried deeply in some unpublished archives or hidden from us in another way. The other stakeholders have all been forgotten in the meantime. The answer to the affair possibly lies elsewhere. If we argue that Glozel was not simply a hoax, then we have to go back and delve more deeply into our knowledge of ancient writing in the 1920s.

In 1923, the archaeological breaking news was the discovery of the sarcophagus of King Ahiram in Byblos by the French archaeologist Pierre Montet. ${ }^{21}$ The antiquity of the find was confirmed by the discovery of several inscribed Egyptian vases inside, which were dated to the reign of Ramses II (1303-1213 вCE). The sarcophagus itself was inscribed in the Phoenician alphabet. In 1924, this discovery allowed René Dussaud to make an assumption just before the discovery of Glozel that Semitic people had invented the alphabet. ${ }^{22}$ This conclusion was first announced at the Académie des Inscriptions et Belles-Lettres in Paris on 14 March 1924. The discovery was published widely in newspapers and scientific journals alike. During the same period, books were written for a more general audience including copies of other antique inscriptions known in the 1920s, meaning that any forger who wanted to 'invent' a new form of writing only had to select, copy and mix letters from ancient texts and re-format them. The main issue here is not as much identifying the forger as reaching an understanding as to why such a forgery developed in the first place.

During the first quarter of the twentieth century, two main theories existed in archaeology and history: Diffusionism and Evolutionism. As archaeology focused mainly on great civilisations (Greek, Egyptian, Near Eastern), the temptation to see the influence of the East on any aspect of a particular civilisation was paroxysmal: ex Oriente lux... Dating methods were imperfect and based on cross-dating. Some absolute chronological links may well have existed between Egypt and Greece, for instance, but these links disappear for the rest of Europe as no written documents exist there. Parallels were then researched by examining the shape of the objects, their style or their decoration..$^{23}$

In this methodology, the existence of a European writing form dating back to the Neolithic period was a contradiction to known wisdom and official conclusions about the origin of the alphabet. From this perspective, the only way forward was to consider Glozel as a testimony of the origin of writing in France from an evolutionary point of view. The alphabet has always been considered

21 See Montet 1923 and 1928 for the final report.

22 Dussaud 1924, 155 and 1927.

23 Renfrew 1983, 118-120, Fig. 21. 
the epitome of ancient writing, at the origins of our own system of writing. Perhaps an unknown people had developed their own civilisation in Glozel, alone, well before the great civilisations of Antiquity - this fact would have incarnated the triumph of Europe against the East. This point of view should be considered in its proper context.

At the beginning of the twentieth century, it was still possible to imagine civilisation emerging with a linear development and cumulative steps. The invention of writing, and especially that of the alphabet, would have been one of these steps, but probably totally disconnected from the social or economic needs that we consider now. The entire affair goes far beyond the social promotion of a modest peasant family, and far beyond the archaeology of the Bourbonnais. The Glozel affair helped to shed some light on a poor part of the country far from the richer regions and towns, and forgotten by the Republic in the difficult economic context of the 1920s. It is probably best interpreted within the historical context of the period, viz. in view of Europe's position in the world, France's position within Europe, the need for identity, the rise of antiSemitic ideas, and other forces which may have had an influence. ${ }^{24}$

It is still possible to visit Glozel Museum, ${ }^{25}$ which is one of the oldest in the Bourbonnais, over at Émile Fradin's farm. It is open every day and is often full of curious visitors who want to see the entire collection of artefacts under the auspices of the descendants of Émile Fradin. Somehow, Glozel is still alive. ${ }^{26}$ The panels by the roadside indicate the site by showing a drawing of an inscribed anthropomorphic pot (for those who are aware of the controversy, because the panel lacks any explicit reference to it). ${ }^{27}$ An image reminiscent of the Glozel tablets associated with a mammoth is painted on the fresco which decorates the main hall of the Université Clermont-Auvergne (Fig. 4).

Despite these conundrums, scientific quarrels and issues of questionable historical accuracy and authenticity regarding the Glozel affair, the Auvergne is one of the most exciting regions in France for an archaeologist to explore: important sites and rich collections of artefacts still need to be extensively studied in themselves. The time for forgeries is over.

24 Delporte 1983.

$25<$ http://www.museedeglozel.com/> (last accessed on 8/4/2019).

26 Gerard 2013.

27 <https://fr.wikipedia.org/wiki/Panneau_de_signalisation_d\%27int\%C3\%A9r\%C3\%AAt_ culturel_et_touristique_en_France\#/media/File:Glozel-panneau-routier-2008.jpg> (last accessed on 8/4/2019). 


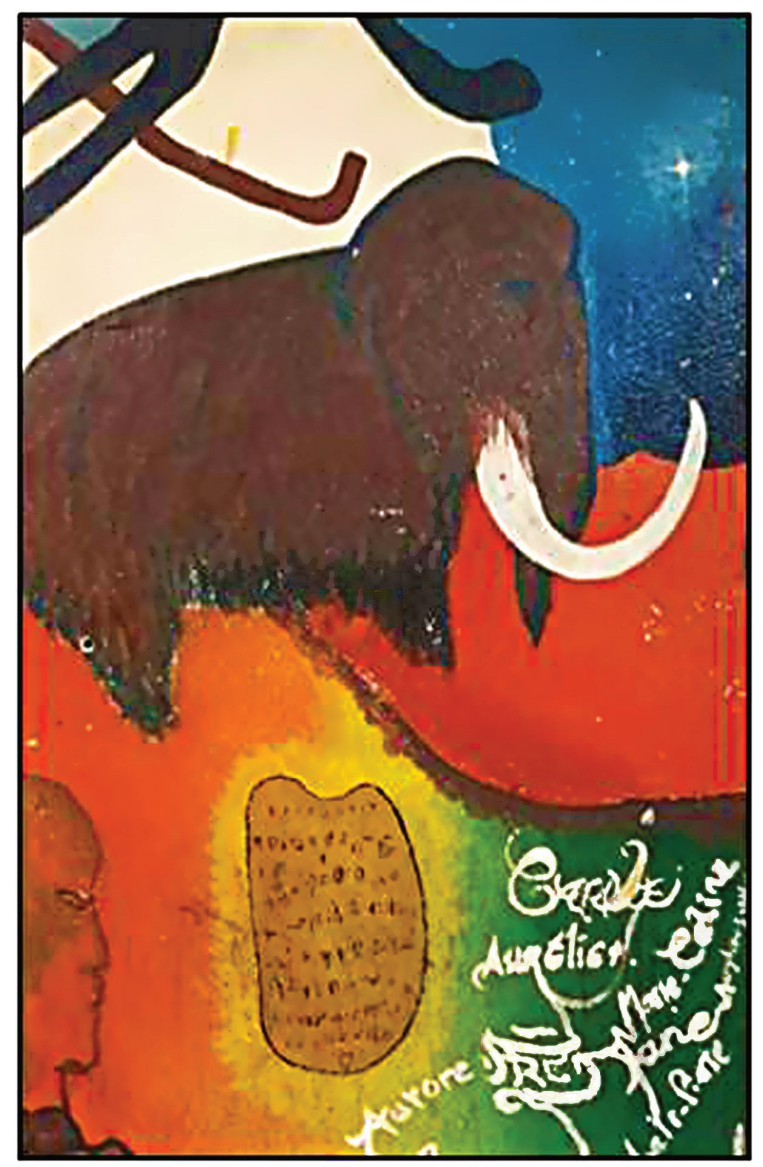

Fig. 4: Detail of a wall-painting in the main hall of the UFR Lettres, Culture et Sciences Humaines of the University Clermont Auvergne (photograph by the author).

\section{References}

Adam, Jean-Pierre (1975), L'archéologie devant l'imposture, Paris: Robert Laffont.

Adam, Jean-Pierre (1983), 'Les inscriptions de Glozel', in Dossiers Histoire et archéologie. 74: 64-73.

Adam, Jean-Pierre (1988), Le passé recomposé. Chroniques d'archéologie fantasque, Paris: Seuil.

Audollent, Auguste (1927), L'énigme de Glozel, Paris: Spes. 
Bessy, Christian, Francis Chateauraynaud, and Pierre Lagrange (1993), 'Une collection inqualifiable : La controverse archéologique sur l'authenticité de Glozel', in Ethnologie française, 23/3: 399-426.

Corrocher, Jacques, Maurice Piboule, and Monique Hilaire (1989), Carte archéologique de la Gaule :03, Allier, Paris: Académie des Inscriptions et Belles-Lettres.

Crawford, T. D. (1977), 'Nouvelles études sur Glozel, suite - Les tablettes inscrites de Glozel', in Revue Archéologique du Centre de la France, 16-3/4, n 63-64: 377-389.

Daugas, Jean-Pierre, Jean-Paul Demoule, Jean Guilaine, Didier Miallier, Pierre Pétrequin, and Jean-Claude Poursat (1995), 'Résumé des recherches effectuées à Glozel entre 1983 et 1990, sous l'égide du Ministère de la culture', in Revue archéologique du Centre de la France, 34: 251-259.

Delporte, Henri (1983), 'Cinquante ans après... Réflexions sur l'affaire de Glozel', in Dossiers Histoire et archéologie, 74: 74-79.

Glozel, l'affaire Dreyfus de l'archéologie (1983) = Dossiers Histoire et archéologie 74 .

Dussaud, René (1924), 'Les inscriptions phéniciennes du tombeau d'Ahiram, roi de Byblos', in Syria, 52: 135-157.

Dussaud, René (1927), Autour des Inscriptions de Glozel, Paris: Armand Colin.

Fradin, Émile (1979), Glozel et ma vie, Paris: Robert Laffont.

Garrod, Dorothy (1968), 'Recollections from Glozel', in Antiquity, 42/167: 172-177.

Gerard, Alice (2013), Glozel. Les os de la discorde, Paris: Le temps présent.

McKerrell, Hugh, Vagn Mejdahl, and Henri François (1974), 'Thermoluminescence and Glozel', in Antiquity, 48: 265.

Montet Pierre (1923), 'Nouvelles archéologiques. Les fouilles de Byblos en 1923', in Syria, 4/4: 334-344.

Montet, Pierre (1928), Byblos et l'Égypte, quatre campagnes des fouilles 1921-1924, Paris: Terre du Liban.

Morlet, Antonin (1928), La Commission internationale, Paris: Paul Catin.

Morlet, Antonin (1932), Petit Historique de l'affaire de Glozel, Paris: Desgrandschamps.

Morlet, Antonin (1955), Origines de l'écriture, Montpellier: Garille \& Castelanu.

Morlet, Antonin and Émile Fradin (1925-1928), Nouvelle station néolithique, 5 vols., Vichy: o. Belin.

Reinach, Salomon (1928a), Éphémérides de Glozel, Paris: Kra.

Reinach, Salomon (1928b), Glozel : la découverte, la controverse, les enseignements, Paris: Kra.

Renfrew, Colin (1983), Les origines de l'Europe : La révolution du radiocarbone, Paris: Flammarion.

Torchet, Nicole, Patrick Ferryn, and Jacques Gossart (1978), L'affaire de Glozel, s.l.: Copernic. Vayson de Pradenne, André (1930), 'The Glozel Forgeries', in Antiquity, 4: 201-222. 
